
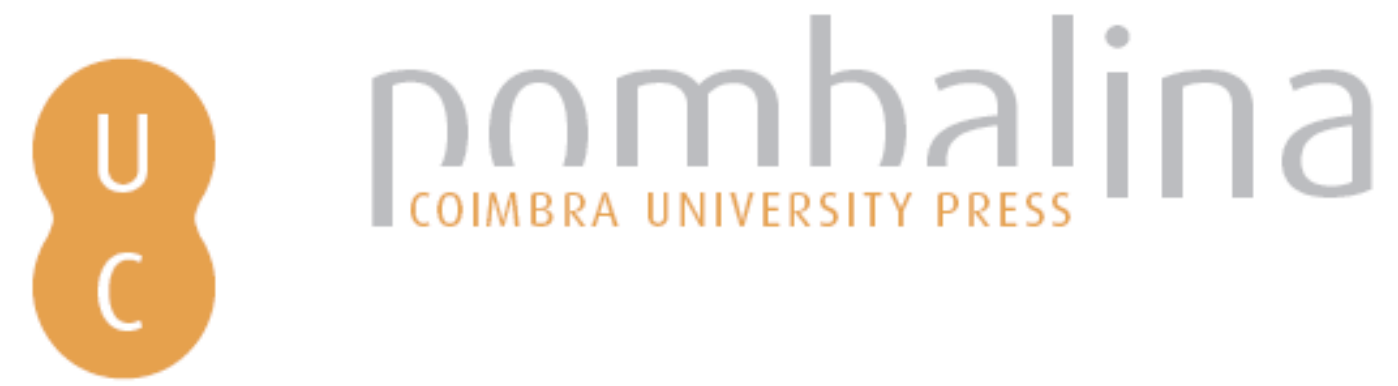

\title{
Painters and poets of the Stieglitz Circle: Marsden Hartley and Hart Crane
}

\author{
Autor(es): Ickstadt, Heinz \\ Publicado por: Imprensa da Universidade de Coimbra \\ URL \\ persistente: URI:http://hdl.handle.net/10316.2/42318 \\ DOI: $\quad$ DOI:https://doi.org./10.14195/978-989-26-1308-6_8
}

Accessed : $\quad$ 26-Apr-2023 10:17:41

A navegação consulta e descarregamento dos títulos inseridos nas Bibliotecas Digitais UC Digitalis, UC Pombalina e UC Impactum, pressupõem a aceitação plena e sem reservas dos Termos e Condições de Uso destas Bibliotecas Digitais, disponíveis em https://digitalis.uc.pt/pt-pt/termos.

Conforme exposto nos referidos Termos e Condições de Uso, o descarregamento de títulos de acesso restrito requer uma licença válida de autorização devendo o utilizador aceder ao(s) documento(s) a partir de um endereço de IP da instituição detentora da supramencionada licença.

Ao utilizador é apenas permitido o descarregamento para uso pessoal, pelo que o emprego do(s) título(s) descarregado(s) para outro fim, designadamente comercial, carece de autorização do respetivo autor ou editor da obra.

Na medida em que todas as obras da UC Digitalis se encontram protegidas pelo Código do Direito de Autor e Direitos Conexos e demais legislação aplicável, toda a cópia, parcial ou total, deste documento, nos casos em que é legalmente admitida, deverá conter ou fazer-se acompanhar por este aviso.

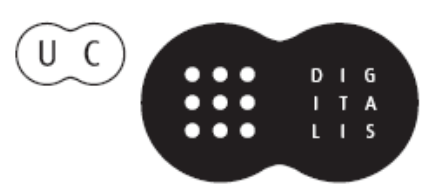





\section{PAINTERSAND POETS OF THE STIEGLITZ CIRCLE - MARSDEN HARTLEY AND H A R T C RANE}

Heinz Ickstadt

Resumo: Marsden Hartley e Hart Crane travaram conhecimento através de Alfred Stieglitz e da galeria 291 durante os anos iniciais da década de 1920. Voltaram a encontrar-se no México, onde ambos beneficiavam de uma bolsa que lhes permitia pintar e escrever na sua procura de uma cultura mais original e "primitiva". Ambos tinham um fascínio ambivalente pelo "culto da morte" na cultura mexicana, com todos os rituais que lhe eram inerentes. O suicídio de Crane, que se afogou no regresso aos Estados Unidos, perturbou profundamente o pintor mais velho, ele próprio atraído pelo suicídio e, tal como Crane, homossexual, assim se passando a rever no destino do poeta. Em celebração do amigo, Crane escreveu um longo poema ("Un Recuerdo - Hermano - Hart Crane R.I.P.") e pintou um quadro de uma beleza enigmática, "Eight Bells Folly, Memorial for Hart Crane" (1933), que ecoa o poema "Voyages" de Crane. O artigo relacionará ambos os poemas e o quadro de Hartley (ele próprio uma interpretação da poesia marítima de Crane), traçando as linhas do território simbólico da morte, amor e desejo que pintor e poeta partilhavam. 
Palavras-chave: Marsden Hartley; "Un Recuerdo - Hermano Hart Crane R.I.P."; Hart Crane; "Voyages".

\begin{abstract}
Marsden Hartley and Hart Crane knew each other via their acquaintance with Alfred Stieglitz and his gallery 291 during the early twenties. They met again in Mexico where both held fellowships to paint and write in search of a more original, more "primitive" culture. Both were ambiguously attracted to the "death culture" of Mexico and the rituals that were part of it. Crane's suicide by drowning on the way back to the U.S. deeply disturbed the elder painter who had often thought of suicide himself and saw in Crane (like him a homosexual) a mirror-image of his own fate. In commemoration of him he wrote a lengthy poem ("Un Recuerdo - Hermano - Hart Crane R.I.P.”) and painted a mysteriously beautiful picture: "Eight Bells Folly, Memorial for Hart Crane" (1933) which echoes Crane's "Voyages." I shall discuss and interrelate both their poems and Hartley's painting (itself an interpretation of Crane's sea poetry), outlining a symbolic territory of death, love and desire that poet and painter shared.
\end{abstract}

Keywords: Marsden Hartley; "Un Recuerdo - Hermano - Hart Crane R.I.P.”; Hart Crane; "Voyages".

The awareness of early American modernists of the artistic revolutions that were going on in Paris, London, or Berlin went hand in hand with their discovery of American ancestries and continuities - the perception of spirituality in the material world as expressed in the writings of the Transcendentalists as well as in the "transcendentalist" paintings of the mid - and late 19th century. By creating a "national landscape," Thomas Cole, Frederic Church 
and other members of the Hudson River School aimed at creating a national art. During the first two decades of the 20th century, Alfred Stieglitz, famous photographer and gallerist, continued that project. ${ }^{1}$ He was the charismatic mentor of a small circle of New York artists who made it the mission of their lives "to enlighten the American public" in matters of art, introduce it to the pathbreaking achievements of European modernism, and help develop an art that would be at once modernist and unmistakeably American. Between 1908 and 1913, his gallery "291" was not only the first in the U.S. to exhibit paintings and sculptures by Matisse, Cézanne, and Picasso, it was also the only place at that time where the artists of an emerging American avant-garde (John Marin, Arthur Dove, Marsden Hartley, Georgia O'Keeffe among others) had the chance to present their works. Poets were also drawn to "291" and became part of the Stieglitz circle. The project to promote "a viable national culture" (Brennan 12) inspired William Carlos Williams to write In the American Grain (1925), an alternative version of America's cultural history, and made Hart Crane compose his mythopoetic The Bridge (1930), a cycle of poems meant to symbolically unite America's mythic past and its urban industrial present in the sublime image, the "unfractioned idiom," of Brooklyn Bridge. ${ }^{2}$

Some of the painters and poets of the Stieglitz circle were friends or cooperated with each other - most famously Charles Demuth and Williams, or Williams and Charles Sheeler. Much less known is the friendship between Marsden Hartley and Hart Crane and the impact Crane had on Hartley's later development as painter. Hartley knew

\footnotetext{
${ }^{1}$ In a letter of 1921 to Stieglitz, Charles Demuth wrote about this common project: "Together we will add to the American scene more than has been added since the [18]60's and 70's - maybe more than they added" (qtd. in Brennan 187).

2 ". . . the truth is," writes Irene Ramalho Santos, "that Brooklyn Bridge was then, and not for Crane alone, the most apt symbol of the growing American nation, a miracle of modern industry, capital, and ingenuity." (196).
} 
Crane from "291" and as a one-time neighbor in Brooklyn; but not only was he more than twenty years older than Crane, he had also been in Europe when Crane came to avant-garde prominence in the mid-twenties. Yet they met again in Marseilles in 1929, when The Bridge was still in print, and then again, in early 1932, in Mexico, when Crane spent there the last months of a Guggenheim fellowship and Hartley the first of his own. Both shared a fascination with the visionary and occult (with William Blake, Walt Whitman and mystics like Jakob Boehme). And they were both homosexuals - Crane occasionally flaunting the fact, Hartley trying to disguise it. In a selfportrait of the late thirties ("Sustained Comedy"), the painter puts on the self-deprecating mask of clown while nevertheless asserting his visionary power: the arrows that pierce his clairvoyant blue eyes may bring suffering but they also generate butterflies, symbols of immortality; the lightning stroke of intuition marks his forehead, birds nest on one of the shoulders of this modern day St. Francis/St. Sebastian, while the other sprouts a bunch of flowers. "The themes of suffering, pain, and mysticism, that were leitmotifs in Hartley's paintings" (Brennan 160), tempt me to compare Hartley's self-portrait with Crane's self-revelatory poem "Possessions" - although Crane's intensities lack the ironic self-reflexivity that marks Hartley's work.

Tossed on these horns, who bleeding dies,

Lacks all but piteous admissions to be spilt

Upon the page whose blind sum finally burns

Record of rage and partial appetites.

The pure possession, the inclusive cloud

Whose heart is fire shall come, - the white wind rase

All but bright stones wherein our smiling plays. (Crane CP: 18) ${ }^{3}$

\footnotetext{
3 The abbreviation $\mathrm{CP}$ will be used in subsequent references to Crane's Complete Poems.
} 
Hartley was devastated when he heard that Crane had committed suicide by jumping overboard the steamer Orizaba on his way back from Mexico on April 27, 1932. Hartley himself had toyed with the idea of suicide, despairing of his isolation as well as of his lack of recognition (and of money). Crane had told him that, after the failure of The Bridge, he had nothing more to say ${ }^{4}$ - a statement of resignation admitting of a promise unfulfilled that horrified Hartley who saw in Crane a younger alter-ego and thus an image of his own possible defeat. He wrote three essays on Crane, published a lengthy commemorative poem: "Un Recuerdo - Hermano - Hart Crane, R.I.P," and painted "Eight Bells Folly" in memory of him. 5 The essays (all of them unpublished) mainly underline their difference of character, as if Hartley wanted to assure himself that Crane's fate could not, would never be, his. They also repeat - without questioning them the pronouncements of poet-critics like Allen Tate and Yvor Winters in whose eyes Crane's epic poem was a "magnificent failure" (cp. Weinberg 163ff). Nevertheless there is a deep sense of personal loss which is echoed in Hartley's poem.

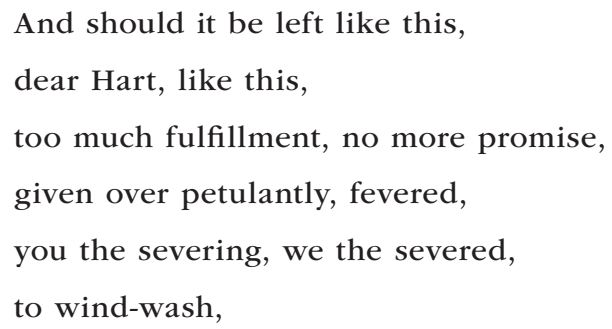

\footnotetext{
${ }^{4}$ In fact, Crane had lost faith in his vision of America's spiritual essence as embodied in the aesthetic and technological achievement of Brooklyn Bridge. Whatever spirituality there was had been defeated by the realities of an overwhelming materialism. In the end, the Bridge represented but "an economical approach to shorter hours, quicker lunches"; and: "I am . . . playing Don Quixote in an immorally conscious way" (Letters 261 \& 260).

5 In her Dictated by Life (1995), Patricia McDonnell follows Hartley's elegy on Crane to Robert Indiana's elegies on Crane and Hartley, thus making the commemorative genre a means of establishing aesthetic continuity in homosexual identity.
} 
wave-flow, wave-toss and thrash,

beating forward, backward, to and fro,

in the unremitting high and low

in the never ending torment of today,

yesterday, so redolent of geniality -

never again to know tomorrow. . .

. .

A beautiful dive, then floating

on his back, waved a hand,

and was seen, no more. .

Gone to the end of the bridge and over

worn with roving the bridge, bridge-rover,

done with all the walking and the stalking,

and all the cheap talking. (CP 119ff, 125, 127)

These excerpts barely represent the uncertainty of Hartley's verse, its wavering between the elevated and the trivial - especially with regard to rhyme and verbal choice. Yet the poem clearly tries to render rhythmically the sea-swell of Crane's post-mortem existence ("an everlasting being in not being", as Hartley had written in one of the essays). In addition, Hartley wove into the texture of his elegy images and motifs of Crane's poetry. ${ }^{6}$ While alive, Crane had written several sea poems, most memorably "At Melville's Tomb" and "Voyages" where the sea became a symbol for the dissolution of the self in love, just as, in the end, he made the sea the medium of his own dissolution in death.

\footnotetext{
${ }^{6}$ In a footnote to his poem, Hartley wrote: "The bridge as symbol in repetition is used here because it was the end of Hart Crane's poetical effort, and he gave out more than once to us here in Mexico, the thought that he had nothing more to say" (CP 333ff.).
} 
No wonder, then, that Hartley painted the sea, in "Eight Bells Folly," as a portrait of Crane's continued "being" after having suffered a sea-change. Accordingly, the painting is highly symbolic and has, as Hartley stated, "a mad look" - the madness, the folly, was Crane's in his dying as well as in the frantic intensity of his living. In the poem, Hartley integrated elements of what had already become part of the Crane legend: eye witnesses on board the ship had seen Crane come up to the surface for a last time, "then floating/ on his back, waved a hand,/and was seen no more." Hartley also included the shark that others asserted to have seen shortly after Crane jumped. The clipper sailing through the dark sea toward a horizon lit by the moon and the sun (or is it the golden apple of heavenly perfection?) may symbolize Crane's (and Hartley's) lifelong yearning for a Beyond ("still one shore beyond desire", as Crane had written in "Ave Maria"). ${ }^{7}$ The number 33 on its sails marks Crane's (and Christ's) age when he died. The eight refers to " 8 bells," or noon, the hour of Crane's suicide. Yet like the number 9, the 8 may also associate infinity and immortality. ". . . [A]nd around the bell," explains Hartley in a letter to his niece, "are a lot of men's eyes - that look up from below to see who the new lodger is to be -" (Weinberg 167).

Hartley painted several elegies in his life - the first in commemoration of his German lover Karl von Freyburg who was killed during the first weeks of WW I. His death made Hartley paint "Portrait of a German Officer" which combines an abstract cubist arrangement of the officer's insignia and uniform with symbols of their friendship - the numbers 24 and 4 referring to Freyburg's age at the time of his death and to his regiment respectively. "Eight

${ }^{7}$ It may also refer to a "recurrent dream he had had, first in 1912, before he went to Europe. . . Each time the dream had involved a boat heading for safety, and each time, after the dream, his life had taken the direction it needed" (Ludington 1992: 235). 
Bells Folly" is situated between this earlier abstract portrait and a commemoration, five years later, of two Nova Scotia fishermen whom Hartley had deeply loved and whom he now intensely mourned. They drowned in 1936, at night, during a fierce storm when they tried to get home from a fishing trip. His "Northern Seascape, Off the Banks" (1936/37) is more representational than both of his previous elegies. It also evokes in its realism and its stylization of waves, rocks, and clouds two painters Hartley greatly admired: Winslow Homer, the realist, and Albert Pinkham Ryder, the painter of the dreamlike and mysterious. The symbolism in "Northern Seascape" is thus more discreet than in "Eight Bells Folly." The two sailing boats scudding toward the horizon may evoke the souls of the two drowned fisherman, but then they may also be just boats on a rough sea. In "Northern Seascape," the rocks, like sharks's teeth, are reminders of the sea's power of death and destruction. There is a Melvillean sense of nature's savage sublimity that informs Homer's sea paintings as well as Thoreau's description of Mt. Katahdin and Cape Cod.

All of Hartley's elegies - painted or written - deal with a tragic loss in his life but in each case they also mark his overcoming despair by creative self-assertion and a new phase in his development as painter. Throughout his career, he had wavered between expressing emotional intensity through abstract expression, on the one hand, and a vehement rejection of the subjective, the annihilation of the self in the object (something he admired in Cézanne), on the other. "To have an eye with brain in it," he wished for in 1919 (Hartley CP: 319); and in an essay of 1928 he went even further in his rejection of the emotionally expressive: "I have joined, once and for all, the ranks of the intellectual experimentalists," possibly thinking of Picabia and Duchamp. "I can hardly bear the sound of the words "expressionism," "emotionalism," "personality". . I no longer believe in the imagination" (Hartley On Art: 71). 
Yet in response to the deep shock caused by Crane's death, Hartley began to artistically reinvent himself. "Crane's art did not save him," observed Jonathan Weinberg. "Yet in working through an artist's death, Hartley discovered his own subject matter" (qtd. in Kornhauser 134). Another critic argues that "Eight Bells Folly" "marked the first time Hartley had overtly connected an event in his life with his art since the 'Portrait of a German Officer' in 1915" (Robertson 98). "My pictures are bound to the mystical more and more for that is what I myself am more and more. . ," Hartley wrote in 1933. "I belong naturally to the Emerson-Thoreau tradition and I know that too well. It is my native substance" (qtd. in Cassidy 108). He now proclaims immersion in a "mysticism of nature" that fused subject and object in the act of imaginative seeing. "The power to 'see' clearly. It is what the artist has with his eye, the power to observe the rhythmic order of the universe. ." (qtd. in Cassidy 6)

That dichotomy in Hartley's aesthetic theory and practice finds an interesting equivalent in Hart Crane's and William Carlos Williams's diverging concepts of the visionary Eye - even though they were both equally committed to the project of creating an original American modernist culture - as is evident in Williams's In the American Grain as well as Crane's The Bridge. ${ }^{8}$ Crane believed that the dynamic curve of the Bridge as much as the dynamics of his own metaphoric densities were both evidence of his visionary "experience of knowledge." They were therefore incarnations - the Word made Flesh in steel, stone and language - of an invisible but all-pervasive creative energy. At the time when Hartley began

8 In a letter to Waldo Frank from Nov. 21, 1926, Crane had written: "Williams' American Grain is an achievement that I'd be proud of. A most important and sincere book. I am very enthusiastic - I put off reading it, you know, until I felt my own way cleared beyond chance of confusions incident to reading a book so intimate to my theme" (O My Land 289-290). 
writing his commemorative poem, Williams published a harsh review of Crane's poetry, denouncing its failure of word and vision. "His eyes seem to me often to have been blurred by 'vision' when they should have been held hard, as hard as he could hold them, on the object." $(1,4)$ Whereas in Crane's eyes, the Bridge - like a Stieglitzsnapshot - was movement caught and turned into timeless presence, for Williams, timelessness was in the experiential process. In his aesthetics of immanence, presence meant constant attention toward an ever changing Now of experience that, for each new moment, had to be caught and represented anew.

Yet when Hartley met Crane in Mexico, Crane's poetic practice had taken a turn of which neither Williams nor Hartley were aware. In his last poem, "The Broken Tower" - the only poem he had written during his year in Mexico - Crane seems to revoke his earlier visionary poetics when he asks the poet to "lift down the eye" (CP 160, emphasis added). It is the reversal of an earlier metaphor he had used in "At Melville's Tomb": "eyes there were that lifted altars" (CP 33, emphasis added) where God is made to exist by the very desire for his existence. Crane was not able to test the implications of this new downward vision. But one may well speculate that it would have been close to Williams's insistence on holding the eye "hard on the object." It might also have found an echo in Hartley's paintings of the thirties and early forties which give evidence of his eye "lifted down" in a precise if condensed (essentializing) representation of things seen. What moves Hartley even closer to Williams is the fact that his reorientation of the eye coincides with his homecoming - the cosmopolitan wanderer between styles and continents not only returning to his native land (something Stieglitz had begged him to do for decades), but to his native region: Maine. No wonder that Williams, the champion of an American literature rooted in the local, praised Hartley in an unpublished review of a 1940-exhibition of his paintings, arguing 
that he painted better than ever before because "the mind, the body and the spirit" had finally come together and brought about "his native completion." 9

Williams's localism (nationalist, yet also universalist) - at a time when regionalists of all kinds claimed to be representative of a truly American art - may seem a far cry from Stieglitz's idea of the artists's involvement in the shaping of an "America still in the making." But it was Hartley himself who believed that his homecoming was indeed a "completion" giving him place, identity, and not least the recognition he had long craved for. As he wrote in "The Return of the Native," one of his best poems:

\author{
it is a smiling festival \\ when rock, juniper, and wind \\ are of one mind; \\ a seagull signs the bond \\ makes what was broken, whole. (CP 251)
}

Cassidy and others have demonstrated that this return "home" was also a retreat - a retreat from all those forces of modernity that Crane had hoped to integrate in his own mythic vision of America. It was a retreat from a commercial urban culture to the spirituality of New England, its transcendentalist "essence" - even though Hartley did not at all mind profiting commercially from his new status as Maine's most prominent painter. It was a retreat also to what he considered the purer and simpler life of farmers and fishermen, and, not least (alas), to the racial purity of Anglo-Saxondom.

Going home to come into his own also meant to (re)take possession of what he considered his by right of birth and artistic

\footnotetext{
${ }^{9}$ Hartley Papers, Beinecke Library.
} 
ancestry: the landscape of New England, and the aesthetic tradition of writers and painters that had elevated its sites to national icons. "I returned to my tall timbers and my granite cliffs because in them rests the kind of integrity I believe in and from which source I draw my private strength both spiritually and esthetically" (On Art 199). As Frederic Church had done before him, he went up Mt. Katahdin to paint the "sacred mountain." Climbing it was nothing less than a religious experience for him: "I know I have seen God now," he confessed to a friend. "The occult connection that is established when one loves nature was complete - and so I felt transported to a visible fourth dimension - and since heaven is inviolably a state of mind I have been there these past ten days" (qtd. in Ludington 1998: 23).

Perhaps it is this sense of finally having found "home" that allows him - in this last phase of his life - to create (almost Crane-like) a symbolic art of secular religiosity which is nevertheless based on the concretely perceived natural object. One might even argue that Mt. Katahdin is for Hartley what Brooklyn Bridge had been for Hart Crane - except that its sublimity was inviolable since its timelessness went back to that primeval Earth before man which Thoreau, in his essay on "Mount Ktaadn," had described in terms of beauty, terror and awe. For Hartley, painting that mountain was "to uncover the principle of conscious unity in all things," and to witness the "living essence present everywhere" - the unity inherent in the forms of mountain and of sea, in the "wave rhythms" connecting all natural phenomena (qtd. in McGrath 187). Reduced to an archaic blackness, set against the essentialized colors of sky (blue), cloud (white), lake (blue), and autumn forest (orange), Hartley's Mt. Katahdin (in "Blue Landscape" or "Autumn - No.2") is primeval and invulnerable - surviving man's savage materialist assault on that wilderness, "awful, though beautiful" (as Thoreau phrased it) that Maine's "sacred mountain" had once embodied in the eyes of poets and 
landscape painters. For Hartley it had become an "icon" of his inmost solitary self as well as an "archetypal symbol of mystic power" forever asserting a creative energy that he himself had ecstatically experienced throughout his life.

\section{Works cited}

Brennan, Marcia. Painting, Gender, Constructing Theory: The Alfred Stieglitz Circle and American Formalist Aesthetics. Cambridge: MIT Press, 2001. Print.

Cassidy, Donna. Marsden Hartley: Race, Region, and Nation. University Press of New England, 2005. Print.

Crane, Hart. The Complete Poems. Ed. Marc Simon. New York: Liveright, 2000. Print.

—. O My Land, My Friends: Selected Letters. Ed. Langdon Hammer and Brom Weber. New York: Four Walls Window, 1997. Print.

- The Letters of Hart Crane, 1916-1932. Ed. Brom Weber. New York: Hermitage House, 1952. Print.

Hartley, Marsden. On Art. Ed. Gail Scott. NY: Horizon Press, 1982. Print.

—. The Collected Poems. Ed. Gail Scott. Boston: Black Sparrow Press, 1987. Print.

Hartley, Marsden. Hartley Papers. Beinecke Rare Book and Manuscript Library, Yale University.

Hokin, Jeanne. Pinnacles \& Pyramids: The Art of Marsden Hartley. Albuquerque: University of New Mexico Press, 1993. Print.

Kelly, Franklin. Frederic Edwin Church and the National Landscape. Washington: Smithsonian Institution Press, 1988. Print.

Kornhauser, Elizabeth Mankin, ed. Marsden Hartley. New Haven: Yale UP, 2002. Print.

Ludington, Townsend. Marsden Hartley. Boston: Little \& Brown, 1992. Print.

- Seeking the Spiritual: The Paintings of Marsden Hartley. Ithaca: Cornell UP, 1998. Print.

McDonnell, Patricia. Marsden Hartley. University of Washington Press, 1997. Print.

—. Dictated by Life. Minneapolis: D.A .P., 1995. Print.

McGrath, Robert. Gods in Granite. Syracuse UP, 2001. Print.

Robertson, Bruce. Marsden Hartley. NY: Harry N. Abrams, 1995. Print.

Santos, Irene Ramalho. Atlantic Poets: Fernando Pessoa's Turn in Anglo-American Modernism. University Press of New England, 2003. Print. 
Tashjian, Dickran. William Carlos Williams and the American Scene, 1920-1940. Berkeley: The University of California Press, 1979. Print.

Thoreau, David. "Ktaadn" and "Cape Cod". Henry David Thoreau. New York: The Library of America, 1985, 593-655 and 849-1039. Print.

Weinberg, Jonathan. Speaking for Vice. New Haven: Yale UP, 1995. Print.

Williams, William Carlos. "Hart Crane, 1899-1932". Contempo II (July 5, 1932): 1 \& 4. Print. 